\title{
The Project-Based Flipped Learning Model in Business English Translation Course: Learning, Teaching and Assessment
}

\author{
Lijun Deng ${ }^{1}$ \\ ${ }^{1}$ School of English for International Business, Guangdong University of Foreign Studies, Guangzhou, China \\ Correspondence: Lijun Deng, School of English for International Business, Guangdong University of Foreign \\ Studies, 2 Baiyun Ave (N), Baiyun District, China. E-mail: rejoice0707@126.com
}

Received: July 17, 2018 Accepted: August 17, 2018 Online Published: August 19, 2018

doi: 10.5539/elt.v11n9p118 URL: http://doi.org/10.5539/elt.v11n9p118

\begin{abstract}
This study designs a project-based flipped learning model for Business English Translation course and tests its efficacy by an empirical study on 65 third-year English major students divided into the experimental class and control class. This study incorporates the learning, teaching and assessment activities of both the students and teachers into a project-based flipped learning model by setting translation projects and dividing the students of the experimental class into a client group and three translator groups in each business translation unit. After one 16-week semester of experiment, this study conducts a post-test, questionnaires and interviews on both the experimental class and control class to test the efficacy of this new flipped learning model. The statistics and facts collected from the above-mentioned research methods suggest that the project-based flipped learning model can significantly enhance the students' motivation to learn out of class, stimulate their participation in class and raise their self-evaluation on translation competence. Additionally, this study finds that the traditional product-oriented summative assessment model is ineffective for Business English Translation course in a flipped-learning context. Therefore, this study tentatively proposes a process-oriented assessment model that is compatible to the flipped learning methodology so as to build integrated flipped classroom pedagogy with teaching, learning and assessment in a virtuous circle of mutual reinforcing.
\end{abstract}

Keywords: flipped learning, translation project, assessment, business English translation course

\section{Introduction}

Flipped learning or flipped classroom has recently become one of the most popularly discussed and employed teaching methodology all over the world. Although not a new pedagogical approach, flipped learning is currently often referenced in information and communications technology (ICT)-supported learning to describe an inversion of the traditional in-class and out-of-class components of the learning and teaching process (Jenkins et al., 2017). Educause (2012) defined flipped classroom as "a pedagogical model in which the typical lecture and homework elements of a course are reversed". As for flipped learning, a more recent definition proposed by the Flipped Learning Network (2015) is "a pedagogical approach in which direct instruction moves from the group learning space to the individual learning space, and the resulting group space is transformed into a dynamic, interactive learning environment where the educator guides students as they apply concepts and engage creatively in the subject matter". Flipped learning methodology places students, rather than teachers as in the traditional teaching methodology, in the center of study and learning activities. Teachers retreat from the center of classroom to provide guidance, answer questions and resolve doubts of students in classroom; the latter have already learned the basics of each lecture through video clips online before class. However, the popularity of the flipped classroom or flipped learning is not matched by widespread clarity over what the approach entails and how it is implemented (Jenkins et al., 2017). As a result, further research and investigation into this approach and the impact it may have on learning are urgently needed and called for (Abeysekera \& Dawson, 2015; O'Flaherty \& Phillips, 2015).

In the last six years, Chinese university classrooms have witnessed far-reaching and innovative application of flipped learning methodology in a wide variety of courses. Nevertheless, when it comes to English-Chinese translation courses in Chinese universities, researches and experimental teaching on flipped teaching methodology are quite limited. Statistics in the following literature review of this study clearly demonstrate that most of the English-Chinese translation classes in Chinese universities are employing the traditional 
instructor-centered and product-oriented teaching methodology, which has sent more and more translation teachers and researchers to reflect and reexamine its effectiveness. Early in the last decade in China, Miao Ju (2007) has commented that the traditional product-oriented teaching methodology in Chinese translation class has weakened the teaching efficacy by the autonomous presentation of translation skills and depressed classroom atmosphere. On the other hand, with the development of modern translation studies in China, more and more scholars have realized that the pedagogy in translation class has to be in line with the nature of translation. As early as in 1994, Daniel Gale has pointed out that since translation is a process that translators constantly revise, negate and finally improve the translated version, translation instructors should focus on translation process instead of merely on the product of translation. Donald Kiraly (2000) and Olivia Fox (2000) have also strongly advocated the process-oriented methodology in translation teaching. Flipped learning methodology, differing from the traditional teacher-and-lecture centered methodology, focuses on the process of learning by giving autonomy in learning to students in a private self-learning space and with individualized self-learning methods.

The application of flipped-learning teaching methodology in English translation class in Chinese universities is a natural outgrowth of researchers' deeper understanding of the nature of translation as well as the urgent need for translation teaching to improve its efficacy and efficiency. Based on the process-oriented nature of translation, this study explores the feasibility of project-based translation tasks in the flipped learning model for Business English Translation course at Guangdong University of Foreign studies, and at the same time, tests the efficacy of this new teaching methodology by a post-test (a Business English translation competence test), questionnaires and interviews. At last, in order to build holistic flipped-learning pedagogy with learning, teaching and assessment in a virtuous circle of mutual reinforcing, a process-oriented assessment model is tentatively proposed by this study as an indispensable component of the project-based flipped learning methodology in Business English Translation course.

\section{Literature Review}

The phrase of flipped learning dates back to early mid 2000s when Jon Bergman and Aaron Sams practiced flipped learning in their own chemistry course and thereafter proposed this practice to change the traditional classroom teaching (Bergmann and Sams 2012). Since then, the research on flipped learning has gained dramatic growth and popularity around the world. In China, the statistics from CNKI (China National Knowledge Infrastructure, an all-inclusive database for Chinese academic journals, publications, conference articles and post-graduate dissertations) show that the number of research publications with "flipped learning" and "flipped classroom" as key words soared from 5 in 2012 to 16,059 in July 2018. Researchers and scholars explored and examined flipped learning/flipped classroom (both terms are translated into the same Chinese expression) in different subjects and from various angels. However, compared to the dramatic development in other academic subjects, the number of research publications on flipped learning in English translation teaching is no doubt very limited. The CNKI statistics collected on July 4, 2018 show that there was 0 research publication before 2014 with flipped learning and translation teaching as key words. The number did grow slowly from 2 in 2014 to 10 in 2015, 61 in 2016, 63 in 2017 and 25 from January 1 to July 4, 2018, with 161 in total in the past four and a half years. These 161 publications can be roughly divided into three categories of empirical studies on translation courses in a flipped learning context, adaptation of flipped learning into broader technical contexts and theoretical reflections on flipped learning. The first category of studies focuses on empirical studies on translation teaching models in various translation courses including MTI course (Dong, Chu, \& Zhang, 2017), College English Translation course (Jiang, 2017), Chinese Culture Translation course (Zhao, 2018) and Technical English course (Ran, 2015). The second type combines flipped learning with broader technical contexts such as SPOC (Zhang \& Tao, 2017), Wechat (Lin, 2017), MOOC (Jiang, 2017; Liu 2016) and Canvas platform (Xie \& Hu, 2017). The last category of study, with it very limited number, questions and reflects on the theoretical foundation and support of flipped teaching by resorting to cognitive science (Gao, 2018) and eco-translatology (Lv, 2016). Needless to say, the above mentioned studies have greatly enriched our understanding of the flipped learning methodology in English translation courses. However, there are much to be desired concerning the depth, framework, model, rationale and practice of flipped learning in English translation teaching in Chinese universities.

\section{Research Purpose and Questions}

This study is based on Business English Translation course provided by the School of English for International Business of Guangdong University of Foreign Studies. The traditional lecture-centered and product-oriented teaching methodology has been implemented in this course. The purpose of this study is to find out an effective flipped learning model compatible to the nature of translation and test its efficacy by an empirical study on different student groups. The following are the introduction to Business English Translation course and the 
related research questions and purpose.

\subsection{Course Introduction}

This two-semester and three-credit course usually starts in the third year of English major students and is divided into two sections: Basics to English-Chinese Translation course in the first semester and Business English Translation course in the second semester. The first section aims to build up the students' fundamental knowledge in translation and related translation skills. Therefore, the first semester usually focuses on teaching translation skills such as addition, omission, embedding, repetition etc. It is conducted in consecutive lectures with topics on the above-mentioned skills. In the second semester, the course is divided into different business theme units including trademark translation, advertisement translation, tourism translation, business correspondence translation, contract translation etc., thus being named as Business English Translation course, as the English source texts are all related to different business themes.

The traditional lecture-centered and product-oriented methodology in a translation class/unit is roughly composed of lectures in class ( $90 \%$ of the class time), after-class assignments (sometimes $10 \%$ or less of the class time) and the teacher's feedbacks on students' assignments. At the beginning of each theme unit, the teacher usually starts with the introduction to the genre and style of the original sample texts, and then analyzes the translation strategies and rationale by presenting the sample translation to the original texts in class. Finally the teacher concludes the class by listing the translation strategies and giving after-class assignments. The very last session of each unit will be ended by the teacher's feedbacks on students'assignments collected afterwards. Since the students will need three to five days to finish the assignment, the teacher usually collects the assignments after a week. Then the teacher will need roughly three to five days to finish reading and scoring all the students' assignments (usually at around 65 assignments from two classes of students). Therefore, it usually takes two weeks for the students to get the feedbacks from the teacher after the class.

At the end of the course, a test-oriented summative assessment is applied to assess the students' performance and competence. Table 1 is the summative assessment form currently applied in Business English Translation course for the third-year English majors at the School of English for International Business of Guangdong University of Foreign Studies.

Table 1. Test-oriented summative assessment form

\begin{tabular}{llllll}
\hline & Assignment 1 & Assignment 2 & Assignment 3 & Assignment 4 & Final test \\
\hline $\begin{array}{l}\text { Percentage } \\
\text { Student } 1\end{array}$ & $10 \%$ & $10 \%$ & $10 \%$ & $10 \%$ & $60 \%$ \\
\hline
\end{tabular}

\subsection{Research Questions}

The following are the specific research questions to be addressed in this study:

1) How are the students satisfied with the traditional lecture-centered and product-oriented teaching methodology in Business English Translation course?

2) What is an effective learning model in Business English Translation course that complies with the nature of translation and is compatible to the flipped learning context?

3) Are the students' competence in translation enhanced under the flipped-learning based model for Business English Translation course?

4) Is the tradition test-oriented summative assessment model feasible in a flipped-learning based Business English Translation course? If no, what is the best way to assess the students in a flipped-learning based Business English Translation course?

\section{Research Method and Procedures}

This study contends that the in-class and out-of-class learning activities of the student, the teaching activities and the assessments are all indispensable parts in building integrated flipped classroom pedagogy. With the aim of implementing and observing the flipped teaching methodology from a holistic perspective in Business English Translation course, this study designs a project-based flipped learning model with emphasis on translation process instead of merely product. Thereafter, the study addresses the question of the efficacy of the flipped-learning model through an empirical study on the experimental class and control class with data and facts 
collected from an English translation competence test, questionnaires and interviews. Last but not least, it is neither rare nor surprising that most of the flipped learning courses are still applying the traditional test-oriented summative assessment method. This study tries to find out a feasible assessment model for the flipped-learning based Business English Translation course.

\subsection{Participants Characteristics}

The participatants of this experimental study were 65 third-year English-major students from the School of English for International Business of Guangdong University of Foreign Studies. The students were from two different paralleling classes with the same major. Statistics collected from the scores of the students in the translation part of the Comprehensive English tests of the two classes at the end of their second year showed that they were of the same level. The average score of class 1 was 15.45 and that of class 2 was 15.51 , with a total of 20 points in the translation section. The slight difference of 0.06 between the average scores of the two classes made them the perfect choice for the experimental group and control group of this study.

\subsection{Experimental Manipulations}

Class 1 was chosen to be the experimental group (thereafter called as the experimental class) and class 2 the control group (thereafter called as the control class). The control class was put in the traditional translation teaching context, which has been applied in Business English Translation classroom at the School of English for International business for the last ten years. The traditional test-oriented summative assessment model was applied in the control class. The experimental class participated in the project-based flipped learning model which was designed by this study in light of the nature of translation. Afterwards, this study examined the efficacy of the projected-oriented flipped learning model by statistics generated from a post-test (English translation competence test), questionnaires and interviews on both the experimental class and control class.

\subsection{Procedure}

The 32 students of the experimental class were divided into one client group and three translator groups. The translation project was to be accomplished thoroughly in and out of class in each theme unit. The client group was the party to find a theme-related source text and initiate the translation project. The three translator groups were the party to take on the project and provide the best possible translation to their client. At the conclusion of the translation project, the client group chose the best translation with standards settled down at the beginning of the project. The study included the learning and assessment activities of both the students and the teacher before, in and out of the class in accomplishing the project so as to construct integrated flipped learning pedagogy in Business English Translation course. It is worth mentioning that the students switched their roles as clients and translators in each theme unit so that every student would have the chance to stand in different positions of different parties in translation projects.

Diagram 1 illustrates how the project-based flipped learning model works in the experimental class by taking the unit of English Contract Translation as an example.

\subsubsection{Before Class}

Firstly, the teacher uploaded the teaching video clip and on-line study checklist exercises onto Blackboard platform and gave access to the students. After learning the video themselves, all the students (including the client and translator groups) were required to finish the checklist exercises so that they would not miss any important information in understanding the genre of the original text and acquiring the skills that would be useful in the future translation.

Secondly, the client group was asked to select an appropriate English contract text as the translation project and discuss it with the teacher. They were supposed to set up standards and expectation for the desired translation.

\subsubsection{The First Session of Class}

The client group presented the selected source text as a real business translation project to the three translator groups with clear-cut requirements and standards for the translated version.

Each translator group took on the project and started group translation by dividing up the work and discussing the genre and requirements of the source text. Each group member should be responsible for a passage of the text and make the best use of references, dictionaries and translation tools. When they finished their own parts, they integrated other group members' work into the first draft of their translation. Thereafter, they discussed the difficulties they met in translation and wrote down their translation logs. The logs were written records of their conscious choice of skills, revision and difficulties during the course of translation. Then they worked together to revise the first draft and produce the second translated version and then submitted it to the client group. 
However, this was not the end of what the translator groups needed to do in the first session. Since they were the active participants of the translation project and thus the best observers of each other's performance, they were asked to fill in a peer review form meticulously designed by this study so that first-hand feedbacks and assessments on each group member could be collected from the peer review forms.

\subsubsection{After the First Session of Class}

The three translator groups submitted their own translations to the client group. The latter party evaluated the translations and chose the most preferred version by using the same requirement and criteria set by themselves. They were not supposed to give traditional scores to the three translated versions. Instead they presented the reason why they would prefer this version to the other two in written form and wrote comments and suggestions on each translator group's work. Their responsibilities also involved reading through the peer review forms and translation logs of all three translator groups so that they could observe the skills the translators had resorted to and the consideration of translators in solving their problems in the process of translation.

\subsubsection{The Second Session of Class}

In the second session of class, which usually was the first 30 minutes of the next class, the client group announced their choice of the best translation and made public comments on the translation of each translator group. The client group presented their written comments and suggestions to three translator groups. Thereafter, the whole class discussed and communicated their personal experience in class.

The teacher, as the director-in-general, made final comments on each group's performance and summarized the key notes of this unit.

\subsubsection{After the Second Session of Class}

The teacher uploaded more after-class exercises onto Blackboard platform for the students to strengthen their understanding of this unit. The students should reflect on what they have learned and accomplished during the whole process of flipped learning and write these down in their own translation logs.

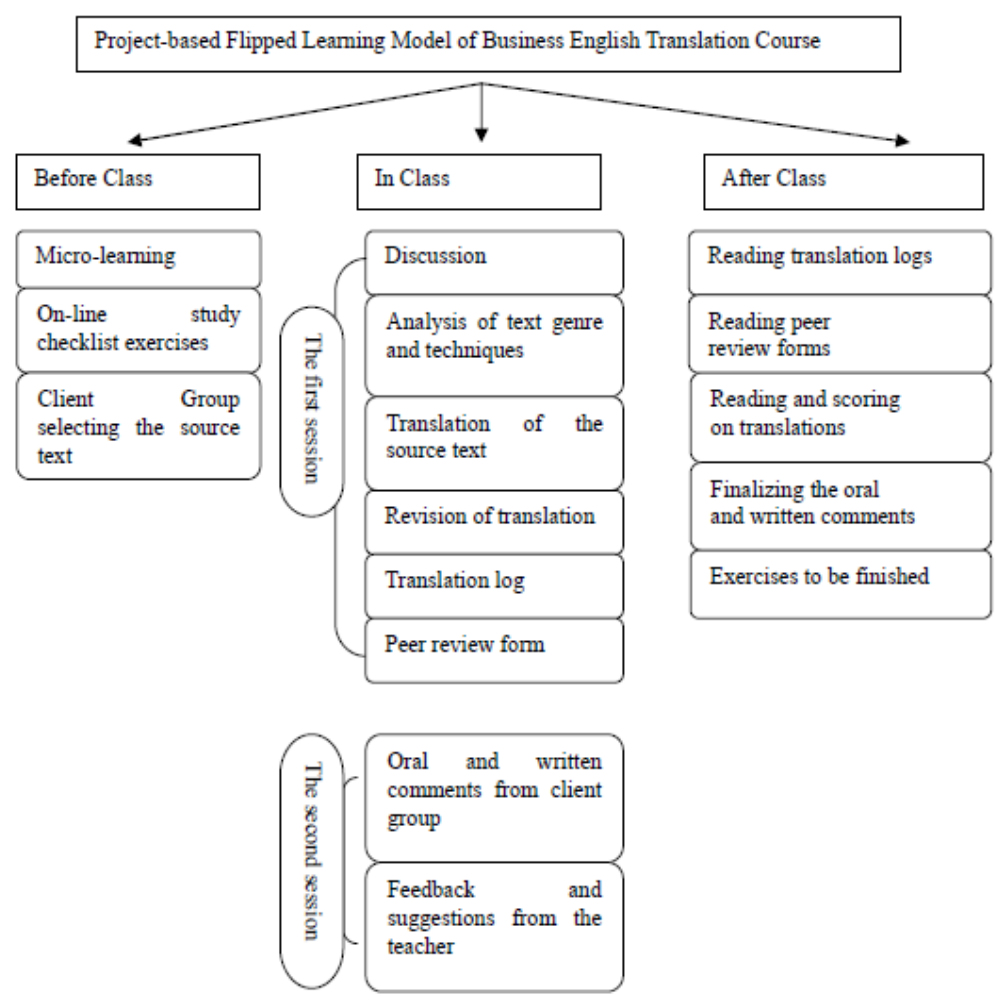

Diagram 1. Project-based flipped learning model of Business English Translation course 


\subsection{The Post-test, Questionnaires and Interviews}

At the conclusion of the 16-week semester, both the experimental class and control class were asked to sit in a post-test (Business English translation competence test). The test was composed of two passages of roughly 500 words, excerpted from an English contact and an English business correspondence. The test time was 80 minutes. In order to obtain unbiased scores, an experienced translation teacher who has never taught these students was invited to assess the 65 test papers.

Along with the post-test, a 15-minute in-class questionnaire was conducted on both the experimental class and control class. The questionnaires were designed as 25 questions on five categories related to translation learning and teaching. The five categories are the students' self evaluation of translation competence, the level of participation in classroom, the motivation to learn out of class, the mastery of translation skills and the satisfaction with the assessment model. For each category to be surveyed, there were five questions meticulously designed with responses from 1 to 5 to indicate the extent to which the participants agree or disagree with the statement.

Independent interviews were made on 10 students from each class so as to obtain firsthand personal feedbacks on the project-based flipped learning methodology. Each interview lasted for 5-7 minutes with questions on the individual learning experience. With the same purpose of obtaining objective feedbacks and judgements, two teachers who have no involvement with teaching activities in the two classes were invited to be the interviewers.

\section{Results}

The following three sections are the results collected from the above-mentioned post-test, questionnaires and interviews.

\subsection{Data from the Post-test}

Table 2 shows the competence test results of the experimental class and the control class. After the 16-week project-based flipped learning model, the experimental class has obtained a relatively higher average score of 84.4 (100 total), which was not very often observed in a standard test in Business English Translation course with traditional teaching methodology. As can be seen in Table 2, the average score of the control class is 79.8, 4.6 points lower than that of the experimental class. It can be safely concluded that the project-based flipped learning model has in effect enhanced the students' translation competence. What's more, the standard deviation of 8.716 of the experimental class also clearly demonstrates that the difference between individual learners in the experimental class is greatly reduced, comparing to 12.364 of the control class. It is a proof that this new learning model is more effective in engaging more students in productive learning in and out of class with the carefully-designed project translation tasks. The $\mathrm{T}$ value of -3.456 and the $\mathrm{P}$ value $(.011<.05)$ collaborately indicate that the difference in translation competence between the experimental class and control class is significantly greater after the implementation of the flipped learning model.

Table 2. Translation competence test result

\begin{tabular}{llllll}
\hline & $\mathrm{N}$ & Mean & Standard Deviation & $\mathrm{t}$ & $\mathrm{p}$ \\
\hline Experimental group & 32 & 84.4 & 8.716 & & \\
Control group & 33 & 79.8 & 12.364 & -3.456 & 0.011 \\
\hline
\end{tabular}

\subsection{Data from Questionnaires}

The descriptive statistics collected from questionnaires are shown in table 3. The data on the first measurement domain suggest the majority of the students in the experimental class rated high on their self-evaluation on translation competence with a mean of 4.40 ( 5 in total) and a standard deviation of only 0.29 . This indicates that the 16-week experiment on the project-based flipped learning methodology has statistically enhanced the students' self-confidence and competence in translations tasks, as compared to a mean of 3.76 with a standard deviation of 0.56 in the control class.

The participation of students in classroom has also witnessed a significant improvement from a mean of 3.45 of the control class to a mean of 4.65 of the experimental class. It can be safely concluded that the project-based teaching methodology can exclusively engage each and every student in the translation project in and out of classroom. Meanwhile, there is noticeable difference in the standard deviation between the two classes with 0.36 of the experimental class and 0.21 of the control class. This is presumably caused by the more diversified 
learning methods provided in the flipped learning classroom than in the traditional classroom. It might be concluded that the lecture-centered and product-oriented teaching methodology produces less diversification in the students' response to classroom participation.

The statistics of the motivation to learn out of class does show as great difference as that of the previous domain. However, the higher standard deviation of 0.97 of the experimental class, as compared to 0.46 of the control class, might suggest that the sharpened difference of motivation within the experimental class is caused by the different roles of different student groups. The students in the client group may feel more obligated to study on the genre, style and requirements of an original text since most of their work has to be accomplished out of class, whilst most of the work of the three translator groups is to be finished in class. How to enhance all the students' motivation after class is a question remained to be addressed and further explored in the project-based flipped learning model.

The mastery of translation skills shows less great difference than in the previous two domains, with two means of 3.86 and 3.76 and two standard deviations of 0.79 and 0.89 . This might prove that the traditional teaching methodology still works well in delivering basic knowledge and skills to students. In a flipped learning context, the instructions on basic knowledge and skills are recorded in the video clip for students' self-learning before class. This is an answer and reassurance to the worries about students' inability in self-directed learning without the guidance of the teachers in person.

A significant finding is made from the data of the last measurement domain. There is no much difference in the two groups' response to the satisfaction on assessment models. The two relatively low means of 2.95 and 2.93 with standard deviations of 0.20 and 0.34 clearly indicate that the traditional summative assessment model is not only incompatible with the new project-based flipped learning model but also ineffective even in the traditional teaching model. A new assessment model compatible to the flipped learning methodology in Business English Translation class is urgent needed, because an effective assessment model is an incompatible part of a complete flipped classroom.

Table 3. Data collected from questionnaires

\begin{tabular}{lll}
\hline Measurement Domain & \multicolumn{2}{c}{ Mean \pm SD } \\
\cline { 2 - 3 } & Experimental class $(\mathrm{n}=32)$ & Control class $(\mathrm{n}=33)$ \\
\cline { 2 - 3 } Self-evaluation on competence & $4.40 \pm 0.29$ & $3.76 \pm 0.56$ \\
Participation in classroom & $4.65 \pm 0.36$ & $3.45 \pm 0.21$ \\
Motivation to learn out of class & $3.73 \pm 0.97$ & $3.33 \pm 0.46$ \\
The mastery of translation skills & $3.86 \pm 0.79$ & $3.76 \pm 0.89$ \\
Satisfaction on assessment model & $2.95 \pm 0.20$ & $2.93 \pm 0.34$ \\
\hline
\end{tabular}

All the measurements ranged 1 to 5 .

SD: Standard deviation.

\subsection{Data Collected from Interviews}

From the independent interviews conducted on the 20 students from both the experimental class and the control class, the following facts and feedbacks can be generalized:

1) Students from the control class admitted that they sometimes lacked initiative to participate in Business English Translation class. The teachers were the center of the class/lecture and the atmosphere of the classroom could be quite dull. Another problem reported was the prolonged circle of after-class assignments and the teacher's feedbacks, which will be addressed in the following discussion section of this study in particular.

2) Students from the experimental class expressed strong interest and greater initiatives in the flipped learning methodology. The on-line study checklist exercises and the division of client and translator groups in and out of class were acknowledged by the students as very useful in engaging them, willingly or not, in the learning process. They also commented that the translation log was a very productive means to provide a chance for them to observe and reflect upon their own translation process.

3) Concerns and dissatisfactions about the assessment model were no surprisingly collected from students of 
both classes. Students from the control class unanimously agreed that the traditional summative evaluation model was to some degree subjective. It was hard to evaluate and observe the translator's adaptation, selection and choices in the translation process. As have been concluded from the data collected in the questionnaires, an assessment paradigm suitable to the new flipped learning methodology and reflective of the nature of translation is urgently called for in the flipped classroom of Business English Translation course.

\section{Discussion}

The data and facts collected and analyzed in this study collaboratively highlighted the positive role of the project-based flipped learning methodology in enhancing the student's participation in classroom, motivation to learn and translation competence. The following are reflections and conclusions to the research questions raised earlier in the study.

\subsection{The Efficacy of the Traditional Teaching Methodology in Business English Translation Class}

With regard to the first research questions proposed at the beginning of the study, a safe conclusion can be drawn that the traditional lecture-centered and product-oriented teaching method calls for reform urgently. It is not deniable that the traditional methodology is still effective in imparting basic knowledge and skills of a certain course as it provides direct interactive learning experience between teachers and students in classroom. However, the traditional teaching methodology has led to many problems including limited initiatives in class, lack of interest in translation, depressed classroom atmosphere, poor competence in real translation projects and low efficiency and efficacy of teaching. The nature of translation has demanded that the translation instructors lay more importance on the process of translation, which could hardly be achieved under the traditional methodology in which translations are always presented as a product instead of a process in the product-oriented pedagogical context.

\subsection{The Efficacy of Flipped Learning Methodology in Business English Translation Class}

Under the flipped learning methodology, the teachers retreat from the center of classroom to the role of the leading support-provider for the learning of students. In a flipped-learning based Business English Translation class, the teacher is the knowledge-provider in the video clips before class, problem-solver and chief-coordinator between the client groups and translator groups in class. At the same time, the students are regarded as the center of learning activities. They actively participate in the on-line study before class and take the in-class time as a precious opportunity to solve problems and resolve doubts in translation through communication with their peers and the teacher. Statistics on the students' performance in this study have shown that there is no need to worry about their competence in self-learning without the guidance of teachers in person. Flipped learning methodology has proved to be an efficient way to solve the problems caused by the traditional teaching methodology by providing diversified means and more controllable time for translation students in and out of class to focus on translation process itself.

\subsection{Translation Project as an Effective Means in Flipped-Learning Based Business English Translation Class}

Project-based translation tasks for different student groups of client and translators have statistically proved to be an effective way to incorporate the flipped learning model into Business English Translation class. A business translation project is the best way to bring students into a real business scenario in which they synthesize the skills and knowledge they learned before class with greater interest and clearer purposes. The on-line study checklist exercises make sure that the students will really engage themselves in before-class learning activities. The in-class translation project, the group discussion and revision of translated version, the translation logs and the peer review reforms together leave the students no chance to loosely participate in class. Moreover, all these carefully-designed activities provide precious chances for the teacher to observe and assess the students as real translators accomplishing a real translation project. The switching of roles as clients and translators of the students during the whole 16-week semester also let the students understand what it is like to be a translator in a real business English context. Business English translation, after all, has to serve the market in the end.

\subsection{A Feasible Assessment Model in the Flipped-Learning Based Business English Translation Course}

The traditional summative test-oriented assessment model has been rated as dissatisfying and commented as ineffective as shown in the data of questionnaires and interviews. The subjectivity in assessment is undeniable as the teacher usually serves as the only subject in assessing the students in test papers and after-class assignments. The untimely feedbacks and response on students' assignments and performance naturally caused by this assessment model has led to the problem of lack of compactness and sustainability in translation teaching. As a result, the students lack interest and initiatives in and out of translation class. Most importantly, as have mentioned in the very beginning of the study, any translation teaching and assessment model should answer to 
the nature of translation activity, which is one of constant reflections on the original text, non-retiringly negation of previous choices and endless revision of the target language text. With the statistics drawn from this study, the summative assessment is proved to be in contradiction to the nature of translation.

The project-based flipped learning model, with its focus on the process instead of the production of learning, has already provided solutions to finding a feasible assessment model in Business English Translation course. The on-line study checklists before class, the translation logs, the peer review forms, the translated versions, the teacher's observation of the translator groups' discussion and performance and the feedbacks and comments from the client group should all be the subject components of assessment on each student. The flipped learning model naturally provides the teacher with the new identity as an observer of the process in translation projects in Business English Translation course. Therefore, this study proposes that a process-oriented assessment model will be the answer to the question of what is the best way to assess the students' performance in the project-based flipped learning model in Business English Translation course. In diagram 2 this study tentatively lists the elements that should be included in the assessment procedure before, in and after class in a flipped classroom of Business English Translation course. This study intends to test the efficacy of this assessment model in the following-up research.

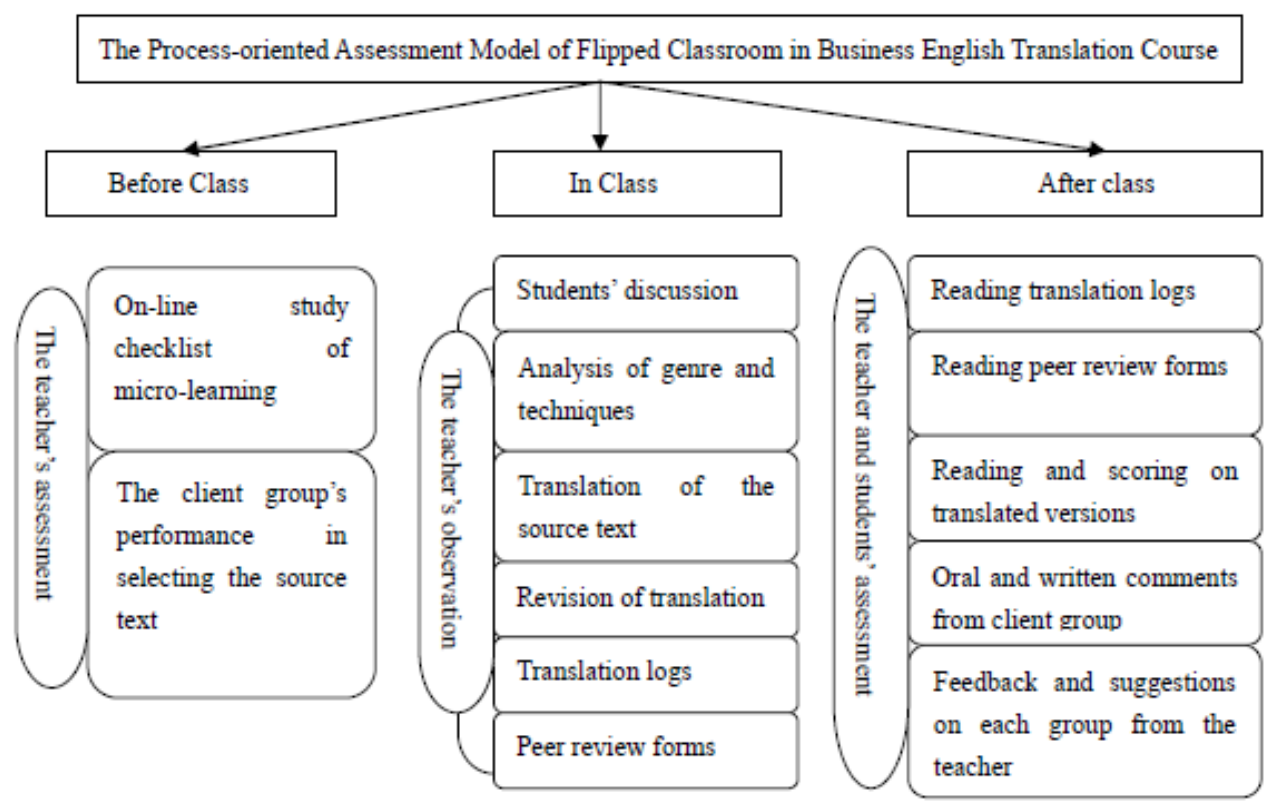

Diagram 2. The process-oriented assessment model of flipped classroom in business English translation course

In conclusion, the project-based flipped learning methodology has been statistically proved to be effective in Business English Translation class not only because it has significantly strengthened the students' learning efficiency and translation competence, but also because it responses to the nature of translation by emphasizing the process of translation activities of students, rather than merely on the translation product. Meanwhile, it has to be admitted that the traditional lecture-centered and product-oriented methodology still works effectively in imparting basic knowledge and skills to the students. Last but not the least, this empirical study has provided statistical proof that a new process-oriented assessment model has to be implemented in the flipped-learning based Business English Translation course so as to achieve a real integrated flipped classroom.

\section{Limitations}

The limitation of this study includes the following two aspects. Firstly, the 16-week empirical study on the flipped learning model in Business English Translation classroom has limited number of participants. Only two classes of students, 65 in total, were included in this study. As translation is in its nature a process of reflection, negation and revising, more learners could be included and observed so as to study the efficacy of the project-based flipped learning methodology in a Business English Translation class. Secondly, the new process-oriented assessment model in the flipped classroom in this study is still in its tentative stage and leaves much to be improved and tested. Without a statistically proved assessment model, it is impossible to conclude 
this study because learning, teaching and assessment, whether in and out of class, are the indispensable parts of a complete flipped classroom.

\section{Acknowledgements}

This paper is funded by the 2017 Higher Education Teaching Research and Reform Project of Guangdong Province "Study on the Process-oriented Assessment Model of Business English Translation Course in a Flipped Learning Context" (No.: 103-XCQ18027).

\section{References}

Abeysekera, L., \& Dawson, P. (2015). Motivation and cognitive load in the flipped classroom: Definition, rationaleand a call for research. Higher Education Research \& Development, 34(1), 1-14. https://doi.org/10.1080/07294360.2014.934336

Barrow, L., Markman, L., \& Rouse, C. E. (2009). Technology's Edge: The Educational Benefits of Computer-Aided Instruction. American Economic Journal Economic Policy, 1(1), 52-74. https://doi.org/ 10.1257/pol.1.1.52

Bergmann, J., \& Sams, A. (2012). Flip your classroom: Reach every student in every class every day. Eugene, Or: International Society for Technology in Education.

Dong, H. X., Chu, S. H., \& Zhang, K. Y. (2017). An Empirical Study on the MTI Teaching Mode of Flipped Classroom Plus Project OrientedLearning Aiming at the Development of Professional Translator Competence. Computer-assisted Foreign Language Education, 176, 49-55.

Educause Learning Initiative. (2012). 7 Things You Should Know About Flipped Classrooms. Retrieved from https://ibrary.educause.edu/ /media/files/library/2012/2/eli7081-pdf.pdf

Flipped Learning Network. (2015). What is Flipped Learning. Retrieved from https://flippedlearning.org/wp-content/uploads/2016/07/FLIP_handout_FNL_Web.pdf

Fox, O. The use of diaries in a process oriented translation teaching methodology. In C. Schaffner \&B. Adab (eds.) Developing Translation Competence (pp. 115-116). Amsterdam, Philadelphia: John Benjamins, 2000.

Gile, D. The process-oriented approach in translation training. In C. Dollerup \& A. Lindeaard (eds.) Teaching Translation and Interpreting: Insights, Aims, Visions (pp. 201-204). Amsterdam: John Benjamins, 1994.

Gao, H. L. (2018). On the Construction of a Flipped Translation Classroom Based on Cognitive Interaction. Foreign Language and Literature, 34(2), 152-156.

Jenkins, M., Bokosmaty, R., Brown, M., Browne, C., Gao, Q., Hanson, J., \& Kupatadze, K. (2018). Enhancing the Design and Analysis of Flipped Learning Strategies. Teaching \& Leaning Inquiry: The ISSOTL Journal, $5(1), 1-12$.

Jiang, C. (2018). Research on Flipped Class Teaching Model Based on MOOC-Take the Course of "English Chinese Translation" Course in Hetao College as an Example. Educational Teaching Forum, 15, 184-185.

Jiang, J. (2017). Flipped Teaching Model in College English Class under the Blended Teaching Methodology. Education Modernization, 131, 130-142.

Kiraly D. (2000). A Social Constructivist Approach to Translator Education: Empowerment from Theory to Practice. Manchester: UK. \& Northampton MA: St. Jerome Publishing, 2000.

Lin, W. (2017). On Interactive Teaching Model of Translation Course Based on Wechat. English Language Teaching, 10. https://doi.org/10.5539/elt.v10n3p21

Liu, L. (2016). English Teaching Model Research Based on Network MOOC. Paper presented at the International Conference on Smart City and Systems Engineering. https://doi.org/10.1109/ ICSCSE.2016.0058

Lv, L. (2016). Research on the Application of the Flipped Classroom in Translation Teaching Based on Eco-translatology for English Majors. Journal of Educational Institute of Jilin Province, 32(3), 73-75.

O'Flaherty, J., \& Phillips, C. (2015). The Use of Flipped Classrooms in Higher Education: A Scoping Review. The Internet and Higher Education, 25, 85-95. https://doi.org/10.1016/j.iheduc.2015.02.002

Ran, H. T. (2015). Flipped Teaching Model in Translation of Technical English Course. English Teachers, 15(22), 103-105.

Xie, K., \& Hu, Q. H. (2017). Research on the Translation Project-based Teaching Model Based on theFlipped 
Classroom under the Support of Canvas Platform. Journal of Chongqing University of Arts and Sciences (Social Sciences Edition), 36(4), 95-101.

Zhang, W., \& Tao, Y. L. (2017). A Study on SPOC-based Flipped Classroom of Translation Course for English Majors. Computer-assisted Foreign Language Education, 174, 27-39.

Zhao, X. F. (2018). The Study on the Blended Teaching Model Based onPAD Class and Flipped Classroom in the Course of "Translation of Chinese Culture". Journal of Hubei University of Education, 35(1), 99-102.

\section{Copyrights}

Copyright for this article is retained by the author(s), with first publication rights granted to the journal.

This is an open-access article distributed under the terms and conditions of the Creative Commons Attribution license (http://creativecommons.org/licenses/by/4.0/). 